\title{
ATOPIC ERYTHRODERMA
}

\section{WITH BILATERAL CATARACT, UNILATERAL KERATOCONUS AND IRIDOCYCLITIS, AND UNDESCENDED TESTES* $\uparrow$}

\author{
BY \\ GURMOHAN SINGH AND J. S. MATHUR \\ From the Departments of Medicine and Ophthalmology, College of Medical Sciences, \\ Banaras Hindu University, Varanasi 5, India
}

VIDAL (1886) first described cataract in young patients subject to attacks of pruritis followed by lichenification and associated with asthma. Andogsky (1914) described four cases of unclassified skin disease with cataract as 'dermatogenous cataract', and Kugelberg (1934) used the term 'syndermatotic juvenile cataract'. Brunsting (1936) reported ten cases of atopic dermatitis with juvenile cataract. Karel, Myška, and Kvíčalová (1965) found three cases of atopic cataract among 128 patients suffering from atopic dermatitis. McDannald (1943) and Berliner (1944) each found one case of associated keratoconus, and Norins and Field (1964) reported a case of atopic dermatitis, atopic cataract, and keratoconus.

Though cataract with atopic dermatitis is not rare, the combination with keratoconus, iridocyclitis, and undescended testes as in the present case could not be found in the literature.

\section{Case Report}

A Hindu boy aged 15 years was admitted to the S. S. Hospital, Varanasi, with generalized scaliness and itching all over the body, loss of vision in both eyes, and inability to open the eye lids The itching and redness of the scalp and face had begun when he was 6 months old, and there had been gradual progressive diminution of vision. At the age of 10 years his eyebrows and eyelashes had started falling out and the axillary and pubic hairs had never grown. There was also a complete absence of sweating. He had not had any corticosteroid or $x$-ray therapy during his illness.

Family History.-The parents were alive and healthy. A sister aged 25 years suffered from asthma. The mother had had no medication during pregnancy.

Examination.-The patient looked very ill, with generalized erythroderma and marked scaliness all over the body. The scalp hair was scanty, and the axillary and pubic hair absent. All the lymph nodes were moderately enlarged. The liver was enlarged four fingers-breadth below the costal margin, the upper border being in the 6th intercostal space. There was a moderate degree of ascites. The feet showed slight oedema. The testes were undescended (Fig. 1, overleaf).

The palpebral apertures were narrow with intense photophobia, yellowish crusts of mucopus on the lid margins, and severe conjunctival congestion and chemosis. After the conjunctivitis had been treated it was possible to examine the eyes (Fig. 2, overleaf).

There were complete bilateral opacities and doubtful keratoconus of the left eye (Fig. 3, overleaf).

Slit-lamp examination of the left eye showed folds in Descemet's membrane, a minute tear at 12 o'clock, and retrocorneal pigmented keratic precipitates. There was no aqueous flare. The lens was completely opaque on the anterior surface A Vossius' ring due to impact of the pupillary margin was also present, and the corneal reflexes were irregular.

* Received for publication August 3, 1966.

$\dagger$ Address for reprints: Dr. Gurmohan Singh, Duhring Laboratories, Dept. of Dermatology, University of Pennsylvania, Philadelphia, Pa. 19104, U.S.A. 


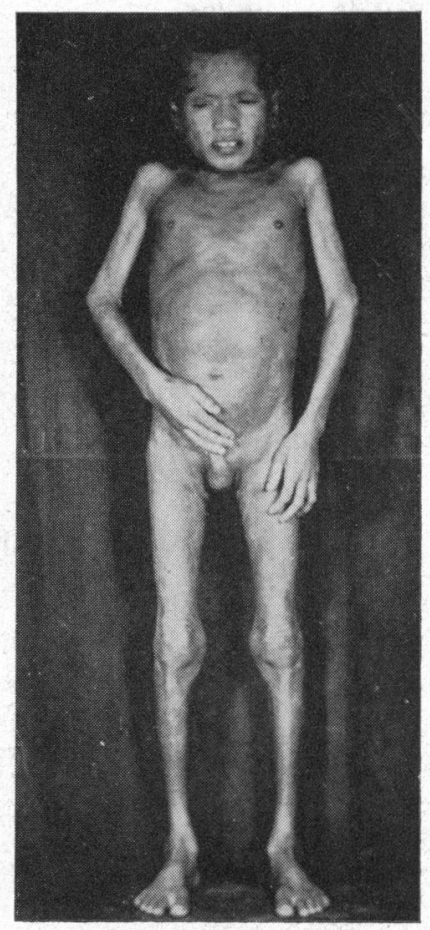

Fig. 1.-Stunted growth, erythroderma, and empty scrotum.

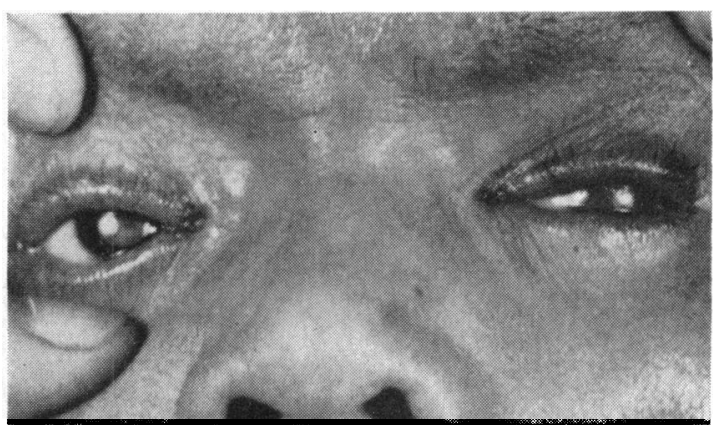

Fig. 2.-Narrowed palpebral apertures; widening was difficult because of photophobia.

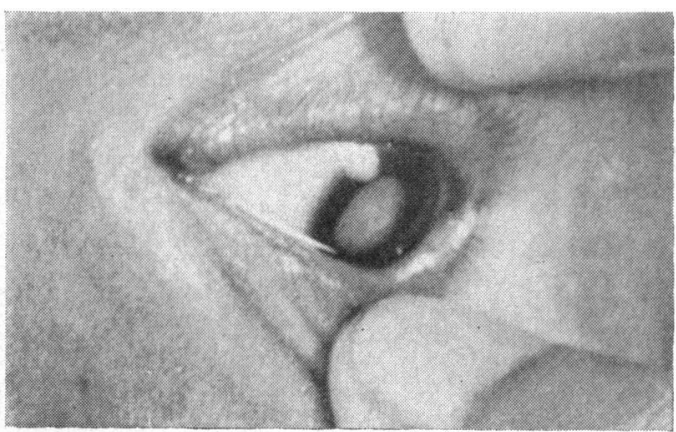

FIG. 3.-Complete lenticular opacity.

\section{Laboratory Investigations}

Total white blood cell count $9,600 / \mathrm{cmm}$., polymorphs 68 , lymphocytes 28 , eosinophils 4 per cent. Haemoglobin 9.2 g. per cent. Erythrocyte sedimentation rate $25 \mathrm{~mm} . / 1 \mathrm{st} \mathrm{hr}$ (Westergren). Serum bilirubin $0.5 \mathrm{mg}$. per cent. Thymol turbidity test 7 Maclagan units. Total protein $4 \mathrm{~g}$. per cent. Albumin/ globulin ratio $2 \cdot 2: 1 \cdot 8$. Serum sodium $130 \mathrm{mEq}$. Serum potassium $5 \cdot 14 \mathrm{mEq}$. Serum chlorides $105 \cdot 36$ mEq. Blood urea $30 \mathrm{mg}$. per cent.

Urine analysis showed nothing abnormal.

Tests for venereal disease were negative.

Ascitic fiuid: Cells 5/cmm., sugar nil, proteins $350 \mathrm{mg}$. per cent., specific gravity 1008 .

Treatment.-The patient was given a high protein diet with prednisolone tablets $30 \mathrm{mg}$. and Dianabol $5 \mathrm{mg}$. per day, and Nephril tablets one per day intermittently. Prednisolone with neomycin ointment was applied to the eyes, and arachis oil with 2 per cent. chloretone to the skin surface.

Progress.-There was marked improvement. The scaliness and erythema almost disappeared, scalp hair began to grow, and sweating became normal. The dose of prednisolone was gradually reduced after 20 days, and that of Dianabol to $2.5 \mathrm{mg}$. per day.

Curette evacuation of the lenticular opacity in the right eye improved the visual acuity to 6/36 with glasses.

\section{Discussion}

The term "atopic erythroderma" was first used by Hill (1950) to describe acute hyperaemia with scaliness, generalized adenopathy, and cold feet in children.

In our patient, infantile eczema progressed to exfoliative dermatitis, perhaps precipitated by injudicious local medication. Anhiderosis due to blockage of the sweat ducts had contributed to the severity of the condition. Hypoproteinaemia was due partly to continuous exudation and loss of scales and partly to liver damage. Beek (cited by Ottolenghi, 1959) postulated that 
dysproteinaemia indicated internal lesions in cases of erythroderma. Continuous loss of scales (rich in serum hepatin) may damage the liver.

The undescended testes appeared to be coincidental.

Involvement of the lens in atopic dermatitis is uncommon, the presence of keratoconus is rare, and associated iridocyclitis has not so far been reported. According to Beetham (1940), such subjects are normal except in weight, and according to Huerkamp (1948) the endocrine system is normal. Brunsting (1936) suggested that the circulating allergens (atopens) might produce cataract by irritating the lens fibres. Waardenburg (1961) thought that, because both lens and skin are derived embryologically from the surface ectoderm, the lenticular opacities might be local manifestations of generalized ectodermal affection. This may also explain in the presence of keratoconus, but not that of unilateral pigmented keratic precipitates and iris pigment on the anterior lens surface.

\section{Summary}

A case is reported of atopic erythroderma with cataract, keratoconus, iridocyclitis, and undescended testes.

We are grateful to Dr. K. N. Udupa, Principal of the College of Medical Sciences, for permission to publish this report, and also to Dr. F. M. Narielvala, Professor of Medicine, and Dr. K. S. Mehra, Professor of Ophthalmology, for advice and guidance.

\section{REFERENCES}

ANDOGSKy, N. (1914). Klin. Mbl. Augenheilk., 52, 824.

BeEtham, W. P. (1940). Arch. Ophthal. (Chicago), $24,21$.

BerLINER, M. (1944). Amer. J. Ophthal., 27, 769.

Brunsting, L. A. (1936). Arch. Derm. Syph. (Chicago), 34, 934.

CORDES, F. C., and CORDERo-MORENo, R. (1946). Amer. J. Ophthal., 29, 402.

HiLl, L. W. (1950). New Engl. J. Med., 242, 286.

HuERKAMP, B. (1948). Klin. Mbl. Augenheilk., 113, 318.

Karel, I., MYšKa, V., and Kví̌alovA, E. (1965). Acta derm.-venereol. (Stockh.), 45, 381.

Kugelberg, I. (1934). Klin. Mbl. Augenheilk., 92, 484.

McDannald, C. E. (1943). Arch. Ophthal. (Chicago), 30, 767.

Norins, A., and Field, L. (1964). Arch. Derm. (Chicago), 90, 102.

OTtOlENGH, F. (1959). In "La colelitiasi et alia hepatologica. Atti del primo Symposium internazionale di epatologia, Chiancino-Terme, 1958", pp. 325-352. Roma.

Vidal, E. (1886). Ann. Derm. Syph. (Paris), 2e sér., 7, 133.

WAARDEnBURG, P. J. (1961). In "Genetics and Ophthalmology", by P. J. Waardenburg, A. Franceschetti, and D. Klein, pp. 901-903. Royal Van Gorcum, Assen, Netherlands. 